\title{
Water Magnetization and Application of Soil Amendments Enhance Growth and Productivity of Snapdragon Plants
}

\author{
Fahed A. Al-Mana, Abdullah M. Algahtani, Yaser H. Dewir,
} Majed A. Alotaibi, Mohammed A. Al-Yafrsi, and Khalid M. Elhindi Department of Plant Production, College of Food and Agricultural Sciences, King Saud University, Riyadh 11451, Saudi Arabia

Additional index words. ferrous sulfate, peatmoss, plant growth, water quality

\begin{abstract}
Freshwater resources are being rapidly depleted because of the increased demand resulting from exponential world population growth and the effects of climate change, especially in arid and semiarid regions (e.g., Saudi Arabia). The present study aimed to examine the changes in growth and inflorescence production of snapdragon (Antirrhinum majus L.) plants in response to irrigation with saline or magnetized water, in addition to application of inorganic and/or organic soil amendments. Three different water types - tap water, magnetized saline water, and nonmagnetized saline water-were used to irrigate $A$. majus plants with or without soil amendments consisting of ferrous sulfate $\left(\mathrm{Fe}_{2} \mathrm{SO}_{4}\right)$ and/or peatmoss. Irrigation with magnetized saline water adversely affected vegetative growth, inflorescence production, mineral contents, and survival rates of $A$. majus plants as compared with irrigation with tap water or magnetized saline water. Nevertheless, compared with unmagnetized saline water treatment, magnetizing nonmagnetized saline water before irrigation significantly improved water characteristics and plant growth and survival. Moreover, the addition of inorganic or organic soil amendments enhanced the growth of $A$. majus plants regardless of irrigation water type. Interestingly, the combination of irrigating with magnetized saline water and soil amendments $\left(\mathrm{Fe}_{2} \mathrm{SO}_{4}\right.$ and peatmoss) significantly enhanced the growth of $A$. majus plants to a level that was comparable to that of control plants irrigated with tap water without soil amendments. Magnetization improved water quality and increased plants' ability to absorb water and nutrients from soil solution. The utilization of magnetized saline water for irrigating food and forage crops either alone or in combination with soil amendments has potential benefits that warrant further research.
\end{abstract}

Plants of the genus Antirrhinum (Plantaginaceae) originated mainly from Europe and spread to Africa and Asia, especially around the Mediterranean region. Its 21 species (The Plant List, 2013) represent a wide diversity of inflorescence patterns, colors, and fragrances. Snapdragon (Antirrhinum majus L.) has been cultivated for its cut flowers and as ornamental garden plants for more than 2000 years (Li et al., 2019). Besides its ornamental uses, snapdragon leaves, inflorescence, and seeds are widely used in traditional medicine for their diuretic, analgesic, and anti-inflammatory activities (Jang et al., 2020). Snapdragon inflorescences possess a wide range of colors and fragrances, making it one of the most important and valuable ornamental plants worldwide (Lian et al., 2020). Furthermore, it has a long history of being used as a model

Received for publication 28 Dec. 2020. Accepted for publication 24 May 2021.

Published online 9 November 2021.

We acknowledge Researchers Supporting Project number (RSP-2021/375), King Saud University, Riyadh, Saudi Arabia.

K.M.E. is the corresponding author. E-mail: kelhindi@ksu.edu.sa.

This is an open access article distributed under the CC BY-NC-ND license (https://creativecommons. org/licenses/by-nc-nd/4.0/). plant because of its ease of cultivation, diploid inheritance, short life cycle, and high morphological diversity (Hudson et al., 2008).

Global climate change has led to worldwide water scarcity, resulting in increased demand for freshwater resources especially in arid and semiarid areas, including Saudi Arabia. Thus, there is a critical need for alternative water resources, especially in the agricultural sector, which is the main consumer of freshwater worldwide. In Saudi Arabia, for example, $88 \%$ of the freshwater is used for agriculture (Gabr et al., 2020). An alternative to freshwater is saline water that could be used, after treatment, to irrigate ornamental and landscape plants. If left untreated, the direct application of saline water may adversely affect the growth, flowering, and productivity of different plants. Carter and Grieve (2008) indicated that irrigating two snapdragon cultivars (Monaco Rose and Apollo Cinnamon) with high saline water $\left(14 \mathrm{dS} \cdot \mathrm{m}^{-1}\right)$ led to slight decrease in quality of the produced cut flowers. A treatment option is water magnetization, which can alleviate the harmful effects of salinity and/or drought stress and enhance the physical and chemical properties of soil (Kney and Parsons, 2006; Mostafazadeh-Fard et al., 2011). In this process, saline water is passed through a strong magnetic field that inactivates the salts, thus reducing the potentially adverse effects of salinity (Teixeira da Silva and Dobránszki, 2014). Moreover, magnetized water is less viscous and better able to penetrate roots, as the magnetization process breaks hydrogen bonds, which minimizes intermolecular interactions that lead to enhanced water absorption in roots (AbdulQados and Hozayn, 2010). Magnetization of irrigation water significantly enhanced yield and growth of cow pea (Vigna unguiculata variety Kanakamani) plant (Surendran et al., 2016). Different growth and photosynthetic parameters of maize plants irrigated with magnetically treated water was better than those of the control group (Ghanati et al., 2015). In a laboratory experiment, magnetized water significantly enhanced germination percentage and seedling vigor index of wheat, tomato, and pea plants (Selim et al., 2013). The same plants irrigated with magnetic field-treated water in greenhouses showed enhanced leaf relative water content, specific leaf area, leaf area per plant, and plant height that led to significant enhancement in yield (Selim et al., 2013). In another study, Selim and El-Nady (2011) showed that growth characteristics, proline contents, water relations, and photosynthetic pigments of tomato seeds irrigated with magnetized water and magnetized tomato seeds were better than those of control plants under water deficit conditions. Based on their results, they concluded that water magnetization may act as a protective factor against the adverse effects of drought stress. Nevertheless, reports regarding the protective effects of magnetization against water salinity are lacking. In the current study, effects of irrigation with magnetized saline water on plant growth were examined.

Another means of alleviating the adverse effects of saline water irrigation is the addition of soil inorganic and/or organic amendments. For example, organic amendments increase the amount of organic matter in the soil, resulting in better aeration and porosity, moisture retention, as well as increased microbial activity (Goyal et al., 1999). Ferrous sulfate $\left(\mathrm{Fe}_{2} \mathrm{SO}_{4}\right)$ and peatmoss are inorganic and organic soil amendments that are widely used in agricultural practices. Therefore, we aimed to examine the growth performance and inflorescence production of $A$. majus plants in response to irrigation with untreated or magnetized saline water, as well as the same irrigation treatments combined with the application of inorganic and/or organic soil amendments.

\section{Materials and Methods}

Plant material, seed germination, and seedlings growth. Seeds of A. majus 'Montego Pink' were obtained from Muller Bloemzaden BV, Lisse, the Netherlands, and sown in foam trays $(30 \mathrm{~cm} \times 30 \mathrm{~cm}: 45$ cells per tray) containing peatmoss. The trays were kept in the nursery of Sustainability and Environmental Development Department, King Saud University, Riyadh, Saudi Arabia, 
at $24 / 20^{\circ} \mathrm{C}$ day/night air temperature with an 11-h photoperiod provided by white, fluorescent tubes and $70 \% \pm 2 \%$ relative humidity (RH). Each tray was watered manually with reverse osmosis water (Flexeon AT-1000 Reverse Osmosis Commercial System 1000 GPD; ESP Water Products, Sunnyvale, TX) using $10-\mathrm{L}$ watering cans every $4 \mathrm{~d}$. Thirty days after sowing, all seedlings were transferred to plastic pots $(15 \mathrm{~cm}$ diameter, $15 \mathrm{~cm}$ deep, with 4 drainage holes each) filled with peatmoss and grown in a greenhouse for two weeks before transferring to permanent location (Fig. 1A and B).

Experimental design. Split-plot design was followed with the main plots represented by different water type (tap water, nonmagnetized saline water, and magnetized saline water) and the subplots represented by soil amendment type (without amendments, peatmoss, $\mathrm{Fe}_{2} \mathrm{SO}_{4}$, and $\mathrm{Fe}_{2} \mathrm{SO}_{4}+$ peatmoss). Subplots were randomly distributed and replicated thrice with 10 lines in each plot. Each plot was $4 \mathrm{~m}$ long and $1.6 \mathrm{~m}$ wide. Spaces between lines and plants were adjusted to 0.4 $\mathrm{m}$ (4 plats in each line). The whole experiment had 36 plots with 40 plants each; hence, the total number of individuals in the experiment was 1440 plants.

Irrigation and soil amendment treatments and growth conditions. After $10 \mathrm{~d}$ of growth in the greenhouse, the seedlings were transferred from pots to the permanent experimental site located at King Saud University Nursery, Riyadh, Saudi Arabia. Before the transfer, the top $50 \mathrm{~cm}$ of the soil was totally removed and replaced with equal volume of sandy soil. For the peatmoss treatment, a mixture of peatmoss (Stender $\mathrm{GmbH}$, Schermbeck, Germany) and sand (1:3; v:v) was added to the top $15 \mathrm{~cm}$ of the permanent cultivation soil before transplanting (Fig. 1C and D). In each plot, $0.16 \mathrm{~m}^{3}$ peatmoss was added. For the $\mathrm{Fe}_{2} \mathrm{SO}_{4}$ treatment, $100 \mathrm{~g}$ of the chemical was dissolved in $10 \mathrm{~L}$ of water and added to the designated plots after the emergence of the third leaf of the $A$. majus

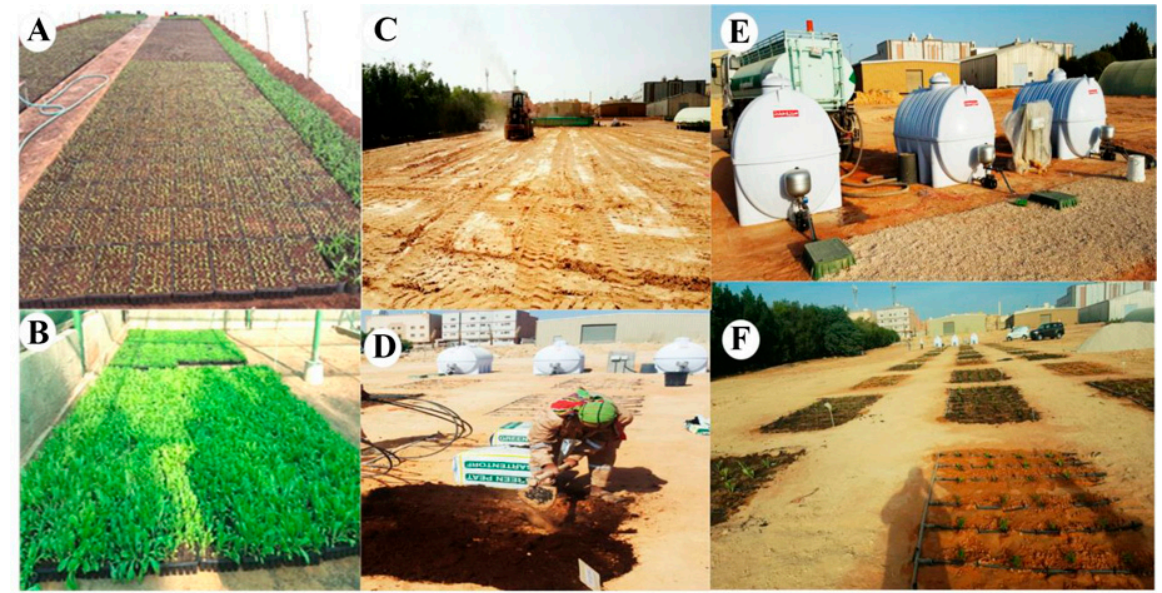

Fig. 1. Seed germination and seedling growth of A. majus and preparation of the experimental site. (A) Seedling emergence after $10 \mathrm{~d}$ in the nursery, (B) hardened seedlings after $30 \mathrm{~d}$ in the greenhouse, $(\mathbf{C}$ and $\mathbf{D})$ preparation of the experimental blots, (E) irrigation water tanks, and (F) cultivated seedlings and the drip irrigation system. plants. The final concentration of added $\mathrm{Fe}^{2+}$ was $20.5 \%$. All plants were fertilized directly after transplanting and two months after transplanting with nitrogen, phosphorus, and potassium (NPK 20:20:20 Sangral; SQM Europe $\mathrm{NV}$, Belgium; $8 \mathrm{~g}$ for each plant).

Three tanks $(5000 \mathrm{~L})$ of a drip irrigation system (installed before the start of the experiment) were filled with the three irrigation water types. The specifications of the drip lines used to irrigate the snapdragon plants were as follows: a flow rate of $8 \mathrm{~L} \cdot \mathrm{h}^{-1}$ with an installed pump of 2 bar pressure (Fig. 1E and F). Irrigation interval was determined according to the irrigation water requirements of the snapdragon plants along the growth season. Control and nonmagnetized saline water were applied directly to plants, while nonmagnetized saline water was magnetized during the whole irrigation period $(10 \mathrm{~min})$ using 1500-gauss 3 -unit magnetization system (Magnetic Fluid Conditioner 8000 GMX; GMX Corporation, Chino, CA). The plants were spaced $40 \times 40 \mathrm{~cm}$ apart and each plant had a separate dripper for irrigation.

Analyses of soil and irrigation water. Soil samples (up to $30 \mathrm{~cm}$ deep and $5 \mathrm{~cm}$ diameter) were collected from the experimental site to analyze their physical and chemical properties according to methods described by Black (1965). Soil electrical conductivity (EC), $\mathrm{pH}$, organic matter content, and cation exchange capacity (CEC) were measured according to Page (1982). The $\mathrm{pH}$ and EC of the soil were measured using a $\mathrm{pH}$ meter (Orion star A211; Thermo Fisher Scientific, Waltham, MA) and a conductivity meter (Orion star A212; Thermo Fisher Scientific), respectively.

Water chemical characteristics [EC, $\mathrm{pH}$, and sodium adsorption ratio (SAR)] were analyzed following the methods described by Page (1982). We also measured the levels of dissolved cations [calcium $\left(\mathrm{Ca}^{2+}\right)$, magnesium $\left(\mathrm{Mg}^{2+}\right)$, potassium $\left(\mathrm{K}^{+}\right)$, and sodium $\left.\left(\mathrm{Na}^{+}\right)\right]$ and anions [chlorine $\left(\mathrm{Cl}^{-}\right)$, bicarbonate
$\left(\mathrm{HCO}_{3}{ }^{-1}\right)$, carbonate $\left(\mathrm{CO}_{3}{ }^{2-}\right)$, and sulfate $\left.\left(\mathrm{SO}_{4}{ }^{-2}\right)\right]$ in the three types of irrigation water using Perkin Elmer NexION 300D ICP (inductively coupled plasma) Mass Spectrometer (Perkin Elmer, Waltham, MA) as described by Allen (1989). Three replicates were analyzed for each type of irrigation water.

Analyses of plants. The experiment was ended $90 \mathrm{~d}$ after transplanting (at the flowering stage). Thirty individual plants from each treatment were collected for further analysis. As indicators for vegetative growth, we measured stem diameter $(\mathrm{cm})$, plant height $(\mathrm{cm})$, number of branches per plant, and number of leaves per plant. Moreover, shoot dry mass (g) was measured after air-drying the plants in an oven for $72 \mathrm{~h}$ at $70^{\circ} \mathrm{C}$. The total plant leaf area $\left(\mathrm{cm}^{2}\right)$ was estimated using a portable leaf area meter (LI-3000C; LI-COR Biosciences $\mathrm{GmbH}$, Homburg, Germany).

The number of inflorescences per plant and days to flowering were monitored to indicate the changes in inflorescence production of $A$. majus plants. Similar to shoot dry matter, inflorescence dry mass was measured after air-drying the flowers of each plant separately in an oven for $72 \mathrm{~h}$ at $70^{\circ} \mathrm{C}$.

The number of plants at the end of the experiment was counted to calculate the survival percentage using the following equation:

$$
\begin{aligned}
& \text { Survical percentage }(\%) \\
& =\frac{\text { Number of surviving individuals }}{\text { Total number of cultivated plants }} \\
& \quad \times 100
\end{aligned}
$$

Dried plant materials were ground into a fine powder using an electric grinder. The contents of $\mathrm{N}^{+}, \mathrm{P}^{+}, \mathrm{K}^{+}, \mathrm{Ca}^{2+}, \mathrm{Mg}^{2+}, \mathrm{Na}^{+}$, $\mathrm{Cl}^{-}$, and $\mathrm{Fe}^{+}$were determined according to standard methods of the Association of Official Analytical Chemists (AOAC, 1990). Measurements were conducted on three different ground plant samples (replicates) collected from each treatment.

Statistical analysis. To evaluate plant responses to different treatments, the Statistical Analysis System (SAS software, version 6.12; SAS Institute, Cary, NC) was used to perform a two-way analysis of on all the studied parameters with irrigation water type and soil amendment as main factors. The interaction between the two factors was also examined. The raw data were used for statistical analysis. The data are presented as means of three replicates \pm SE values. Means were compared using the least significant difference test with $P \leq 0.05$ for comparison of both single and interaction effects (two-tailed) to examine the effects of water type or soil amendment type separately and in combination.

\section{Results and Discussion}

Characteristics of soil and irrigation water. The soil texture was sandy $(90.32 \%$ sand, $7.68 \%$ clay, and $2 \%$ silt), with an average $\mathrm{pH}$ of 7.68 , organic matter content of $1.82 \%$, CEC of $35.99 \mathrm{meq} / 100 \mathrm{~g}$, and electric conductivity of $1.42 \mathrm{dS} \cdot \mathrm{m}^{-1}$. Available soil 
$\mathrm{CaCO}_{3}$ was $2.39 \%$ and soil $\mathrm{N}, \mathrm{P}$, and $\mathrm{K}$ were 45.82, 7.98, and $120.14 \mathrm{ppm}$, respectively.

All types of irrigation water used for the current study had $\mathrm{pH}$ values ranging from 7.0 to 7.9 (Table 1). As expected, tap water was the least saline, with an EC of $0.74 \mathrm{dS} \cdot \mathrm{m}^{-1}$, while magnetized saline water and nonmagnetized saline water had had EC values of 3.7 and $4.0 \mathrm{dS} \cdot \mathrm{m}^{-1}$, respectively. Consistent with the EC values, tap water has the lowest $\mathrm{Na}^{+}$ (7.0 meq $\left.\cdot \mathrm{L}^{-1}\right)$ and $\mathrm{Cl}^{-}\left(8.0 \mathrm{meq} \cdot \mathrm{L}^{-1}\right)$ concentrations and the lowest SAR values (4.0). Meanwhile, magnetized and nonmagnetized saline water share similar $\mathrm{Na}^{+}, \mathrm{Cl}^{-}$, and SAR values that are consistent with their high salinity levels. Other water quality parameters did not vary significantly among the water types, except for the $\mathrm{SO}_{4}{ }^{2-}$ content of nonmagnetized saline water, which was the highest at $5.0 \mathrm{meq} \cdot \mathrm{L}^{-1}$.

Vegetative growth of A. majus plants. All indicators of vegetative growth, i.e., plant height, stem diameter, number of leaves, number of branches, leaf area, and shoot dry matter, were significantly lower in A. majus plants irrigated with magnetized or saline water, compared with those irrigated with tap water (Table 2; Fig. 2). However, irrigation with magnetized saline water alleviated the harmful effects of saline water, as evidenced by the higher values of vegetative growth parameters (Table 2). These results may be attributed to the improved water properties resulting from magnetization (Hilal and Hilal, 2000a). Magnetization regulates the charges of water molecules by breaking the hydrogen

Table 1. Chemical characteristics of different water types used for irrigating Antirrhinum majus L. plants.

\begin{tabular}{lrrrrr}
\hline Characteristics & $\begin{array}{c}\text { Tap water } \\
(\text { control })\end{array}$ & $\begin{array}{c}\text { Magnetized } \\
\text { saline water }\end{array}$ & $\begin{array}{c}\text { Nonmagnetized } \\
\text { saline water }\end{array}$ & $F$-value & $P$ value \\
\hline $\mathrm{pH}$ & $7.0 \pm 0.03 \mathrm{c}$ & $7.2 \pm 0.11 \mathrm{~b}$ & $7.9 \pm 0.23 \mathrm{a}$ & 42.13 & $<0.01$ \\
Electrical conductivity $\left(\mathrm{dS} \cdot \mathrm{m}^{-1}\right)$ & $0.74 \pm 0.01 \mathrm{c}$ & $3.7 \pm 0.21 \mathrm{~b}$ & $4.0 \pm 0.53 \mathrm{a}$ & 81.29 & $<0.01$ \\
Sodium adsorption ratio & $4.0 \pm 0.36 \mathrm{~b}$ & $7.2 \pm 0.61 \mathrm{a}$ & $7.4 \pm 0.42 \mathrm{a}$ & 85.22 & $<0.01$ \\
Cations (meq $\mathrm{L}^{-1}$ ) & & & & & \\
$\quad$ Potassium & $0.3 \pm 0.03 \mathrm{~b}$ & $3.8 \pm 0.51 \mathrm{a}$ & $3.6 \pm 0.64 \mathrm{a}$ & 29.29 & $<0.01$ \\
$\quad$ Magnesium & $3.0 \pm 0.20 \mathrm{~b}$ & $3.8 \pm 0.16 \mathrm{a}$ & $3.6 \pm 0.34 \mathrm{a}$ & 2.14 & 0.03 \\
$\quad$ Calcium & $4.0 \pm 0.68 \mathrm{~b}$ & $5.0 \pm 0.64 \mathrm{a}$ & $5.1 \pm 0.21 \mathrm{a}$ & 10.21 & 0.02 \\
$\quad$ Sodium & $7.0 \pm 0.93 \mathrm{~b}$ & $21.6 \pm 2.18 \mathrm{a}$ & $22.1 \pm 1.72 \mathrm{a}$ & 53.18 & $<0.01$ \\
Anions (meq $\cdot \mathrm{L}^{-1}$ ) & & & & & \\
$\quad$ Chlorine & $8.0 \pm 0.88 \mathrm{~b}$ & $28.0 \pm 1.98 \mathrm{a}$ & $28.0 \pm 2.43 \mathrm{a}$ & 62.71 & $<0.01$ \\
$\quad$ Sulfate & $2.1 \pm 0.51 \mathrm{~b}$ & $2.8 \pm 0.33 \mathrm{~b}$ & $5.0 \pm 0.69 \mathrm{a}$ & 25.33 & $<0.01$ \\
$\quad$ Carbonate & - & - & - & & \\
$\quad$ Bicarbonate & $0.9 \pm 0.03 \mathrm{~b}$ & $1.3 \pm 0.21 \mathrm{a}$ & $0.9 \pm 0.02 \mathrm{~b}$ & 3.21 & 0.04 \\
\hline
\end{tabular}

Values are shown as means \pm SEM. Means in each column followed by a common letter are not significantly different $(P \leq 0.05)$.

bonds, thus changing the water properties (Hachicha et al., 2018). The adverse effects of saline water irrigation may be due to the following reasons: 1) nutrient deficiency resulting from plant roots' inability to absorb essential nutrients because of the competitive effects of salt ions (Hilal and Hilal, 2000b). 2) Excess amounts of salt ions in saline water causes ionic toxicity that affects the overall vegetative growth of the plants by breaking apart the plasma membranes and interrupting essential enzyme activities, leading to disruptions in essential metabolic processes, including protein synthesis, respiration, and photosynthesis (Ferrante et al., 2011; Hilal and Hilal, 2000b). 3) Saline water causes stress that plants respond to by thickening their cell walls (Orcutt and Nilsen, 2000). Saline stress is known to disrupt plant hormonal signals (Munns, 2002). It reduces the levels of hormones involved in cellular division, leading to reduced plant height (Kozminska et al., 2017).

Regardless of the irrigation water type, the addition of different soil amendments enhanced the vegetative growth of $A$. majus plants as compared with the control treatment (Table 2). Among all the soil amendment treatments, the combination of $\mathrm{Fe}_{2} \mathrm{SO}_{4}$ and peatmoss produced the best vegetative growth (Fig. 3). Between $\mathrm{Fe}_{2} \mathrm{SO}_{4}$ and peatmoss alone, the former produced more vegetative growth in A. majus. Both inorganic and/or organic soil amendments enhance the chemical, physical, and even biological characteristics of soil and may provide essential elements required by plants (Halvin et al., 2005). The addition of $\mathrm{Fe}_{2} \mathrm{SO}_{4}$ to soil may reduce $\mathrm{SAR}$ by increasing $\mathrm{CaCO}_{3}$ solubility,

Table 2. Effects of irrigation water type and different soil amendments on the growth of Antirrhinum majus L. plants.

\begin{tabular}{|c|c|c|c|c|c|c|c|}
\hline \multicolumn{2}{|l|}{ Treatments } & Plant ht $(\mathrm{cm})$ & Stem diam $(\mathrm{cm})$ & No. of branches & No. of leaves & Leaf area $\left(\mathrm{cm}^{2}\right)$ & $\begin{array}{l}\text { Shoot dry } \\
\text { matter }(\mathrm{g})\end{array}$ \\
\hline \multicolumn{8}{|l|}{ Irrigation water type } \\
\hline \multicolumn{2}{|l|}{ Tap water (control) } & $20.20 \pm 0.96 \mathrm{a}$ & $1.78 \pm 0.10 \mathrm{a}$ & $11.91 \pm 0.55 \mathrm{a}$ & $117.8 \pm 0.64 \mathrm{a}$ & $1006.6 \pm 9.11 \mathrm{a}$ & $39.03 \pm 0.66 \mathrm{a}$ \\
\hline \multicolumn{2}{|c|}{ Magnetized saline water } & $19.01 \pm 1.11 \mathrm{~b}$ & $1.36 \pm 0.03 \mathrm{~b}$ & $10.91 \pm 0.56 \mathrm{~b}$ & $105.9 \pm 0.97 b$ & $881.2 \pm 6.21 \mathrm{~b}$ & $32.85 \pm 0.84 b$ \\
\hline \multicolumn{2}{|c|}{ Nonmagnetized saline water } & $16.31 \pm 0.63 \mathrm{c}$ & $1.19 \pm 0.01 \mathrm{~b}$ & $8.72 \pm 0.43 \mathrm{c}$ & $87.80 \pm 0.66 \mathrm{c}$ & $717.8 \pm 5.13 \mathrm{c}$ & $28.30 \pm 0.53 \mathrm{c}$ \\
\hline \multicolumn{2}{|c|}{$F$-value } & $10,464.1$ & $4,029.14$ & $9,226.86$ & 220,397 & $41,800.6$ & $15,164.1$ \\
\hline \multicolumn{2}{|l|}{$P$ value } & $<0.01$ & $<0.01$ & $<0.01$ & $<0.01$ & $<0.01$ & $<0.01$ \\
\hline \multicolumn{8}{|l|}{ Soil amendments } \\
\hline \multicolumn{2}{|l|}{ Sandy soil (control) } & $16.74 \pm 0.66 \mathrm{c}$ & $1.21 \pm 0.11 \mathrm{a}$ & $7.92 \pm 0.43 \mathrm{~d}$ & $101.0 \pm 0.55 \mathrm{c}$ & $810.3 \pm 3.18 \mathrm{c}$ & $22.72 \pm 0.84 \mathrm{c}$ \\
\hline \multicolumn{2}{|c|}{ Peatmoss } & $18.19 \pm 0.61 b$ & $1.31 \pm 0.13 \mathrm{a}$ & $9.52 \pm 0.41 \mathrm{c}$ & $102.5 \pm 0.56 \mathrm{bc}$ & $844.0 \pm 3.22 b$ & $36.65 \pm 0.73 b$ \\
\hline \multicolumn{2}{|c|}{ Ferrous sulfate $\left(\mathrm{Fe}_{2} \mathrm{SO}_{4}\right)$} & $18.79 \pm 0.55 b$ & $1.53 \pm 0.09 \mathrm{a}$ & $11.29 \pm 0.88 b$ & $103.8 \pm 0.59 \mathrm{~b}$ & $865.4 \pm 4.18 b$ & $37.57 \pm 0.99 \mathrm{ab}$ \\
\hline \multicolumn{2}{|c|}{ Peatmoss $+\mathrm{Fe}_{2} \mathrm{SO}_{4}$} & $20.30 \pm 0.55 \mathrm{a}$ & $1.72 \pm 0.08 \mathrm{a}$ & $13.32 \pm 1.13 \mathrm{a}$ & $107.9 \pm 0.61 \mathrm{a}$ & $954.3 \pm 5.90 \mathrm{a}$ & $38.95 \pm 1.10 \mathrm{a}$ \\
\hline \multicolumn{2}{|l|}{$F$-value } & 29.29 & 28.81 & 41.93 & 41.85 & 90.57 & 21.44 \\
\hline \multicolumn{2}{|c|}{$P$ value } & $<0.01$ & $<0.01$ & $<0.01$ & $<0.01$ & $<0.01$ & $<0.01$ \\
\hline \multicolumn{8}{|c|}{ Irrigation water type $\times$ soil amendments } \\
\hline \multirow[t]{4}{*}{ Tap water (control) } & Sandy soil (control) & $18.27 \pm 0.27 \mathrm{fg}$ & $1.56 \pm 0.19 \mathrm{~d}$ & $9.97 \pm 0.27 \mathrm{~d}$ & $114.6 \pm 0.43 \mathrm{~d}$ & $938.9 \pm 7.40 \mathrm{~d}$ & $36.81 \pm 0.55 \mathrm{fg}$ \\
\hline & Peatmoss & $19.85 \pm 0.14 \mathrm{~cd}$ & $1.74 \pm 0.15 \mathrm{c}$ & $11.06 \pm 0.42 \mathrm{c}$ & $116.4 \pm 0.41 \mathrm{c}$ & $978.1 \pm 4.94 \mathrm{c}$ & $40.01 \pm 0.25 \mathrm{~cd}$ \\
\hline & Ferrous sulfate $\left(\mathrm{Fe}_{2} \mathrm{SO}_{4}\right)$ & $20.51 \pm 0.24 \mathrm{bc}$ & $1.82 \pm 0.36 \mathrm{~b}$ & $13.11 \pm 0.25 \mathrm{~b}$ & $117.8 \pm 0.76 \mathrm{~b}$ & $1003.0 \pm 5.18 b$ & $41.31 \pm 0.48 \mathrm{bc}$ \\
\hline & Peatmoss $+\mathrm{Fe}_{2} \mathrm{SO}_{4}$ & $22.15 \pm 0.42 \mathrm{a}$ & $2.01 \pm 0.11 \mathrm{a}$ & $15.47 \pm 0.41 \mathrm{a}$ & $122.5 \pm 0.38 \mathrm{a}$ & $1106.2 \pm 12.63 \mathrm{a}$ & $44.63 \pm 0.86 \mathrm{a}$ \\
\hline \multirow{4}{*}{$\begin{array}{l}\text { Magnetized saline } \\
\text { water }\end{array}$} & Sandy soil (control) & $17.19 \pm 0.26 \mathrm{hi}$ & $1.12 \pm 0.19 \mathrm{gh}$ & $8.77 \pm 0.23 \mathrm{e}$ & $102.9 \pm 0.38 \mathrm{~g}$ & $822.2 \pm 6.5 \mathrm{~g}$ & $34.65 \pm 0.52 \mathrm{hi}$ \\
\hline & Peatmoss & $18.69 \pm 0.13$ ef & $1.15 \pm 0.14 \mathrm{~g}$ & $9.73 \pm 0.37 \mathrm{~d}$ & $104.5 \pm 0.36 \mathrm{f}$ & $856.2 \pm 4.33 \mathrm{f}$ & $37.66 \pm 0.26$ ef \\
\hline & Ferrous sulfate $\left(\mathrm{Fe}_{2} \mathrm{SO}_{4}\right)$ & $19.31 \pm 0.23 \mathrm{de}$ & $1.46 \pm 0.34 \mathrm{e}$ & $11.53 \pm 0.22 \mathrm{c}$ & $105.8 \pm 0.68 \mathrm{f}$ & $878.1 \pm 4.50 \mathrm{e}$ & $38.88 \pm 0.46 \mathrm{de}$ \\
\hline & Peatmoss $+\mathrm{Fe}_{2} \mathrm{SO}_{4}$ & $20.85 \pm 0.40 \mathrm{~b}$ & $1.72 \pm 0.11 \mathrm{c}$ & $13.62 \pm 0.36 \mathrm{~b}$ & $110.0 \pm 0.34 \mathrm{e}$ & $968.2 \pm 11.06 \mathrm{c}$ & $42.01 \pm 0.08 \mathrm{~b}$ \\
\hline \multirow{4}{*}{$\begin{array}{l}\text { Nonmagnetized } \\
\text { saline water }\end{array}$} & Sandy soil (control) & $14.75 \pm 0.22 \mathrm{k}$ & $0.96 \pm 0.14 \mathrm{i}$ & $7.02 \pm 0.19 \mathrm{f}$ & $85.6 \pm 0.32 \mathrm{j}$ & $669.7 \pm 5.31 \mathrm{j}$ & $29.72 \pm 0.45 \mathrm{k}$ \\
\hline & Peatmoss & $16.03 \pm 0.11 \mathrm{j}$ & $1.05 \pm 0.11 \mathrm{~h}$ & $7.70 \pm 0.30 \mathrm{f}$ & $86.6 \pm 0.30 \mathrm{ij}$ & $697.6 \pm 3.53 \mathrm{i}$ & $32.30 \pm 0.22 \mathrm{j}$ \\
\hline & Ferrous sulfate $\left(\mathrm{Fe}_{2} \mathrm{SO}_{4}\right)$ & $16.55 \pm 0.19 \mathrm{ij}$ & $1.32 \pm 0.25 \mathrm{f}$ & $9.21 \pm 0.18 \mathrm{de}$ & $87.7 \pm 0.56 \mathrm{i}$ & $715.2 \pm 3.67 \mathrm{i}$ & $33.35 \pm 0.39 \mathrm{ij}$ \\
\hline & Peatmoss $+\mathrm{Fe}_{2} \mathrm{SO}_{4}$ & $17.89 \pm 0.34 \mathrm{gh}$ & $1.43 \pm 0.08 \mathrm{e}$ & $10.87 \pm 0.29 \mathrm{c}$ & $91.2 \pm 0.28 \mathrm{~h}$ & $788.6 \pm 9.01 \mathrm{~h}$ & $36.04 \pm 0.69 \mathrm{gh}$ \\
\hline \multicolumn{2}{|l|}{$F$-value } & 30.22 & 28.39 & 41.16 & 41.63 & 92.66 & 21.04 \\
\hline \multicolumn{2}{|l|}{$P$ value } & $<0.01$ & $<0.01$ & $<0.01$ & $<0.01$ & $<0.01$ & $<0.01$ \\
\hline
\end{tabular}

Values are shown as means \pm SEM. Means in each column followed by a common letter are not significantly different $(P \leq 0.05)$. 


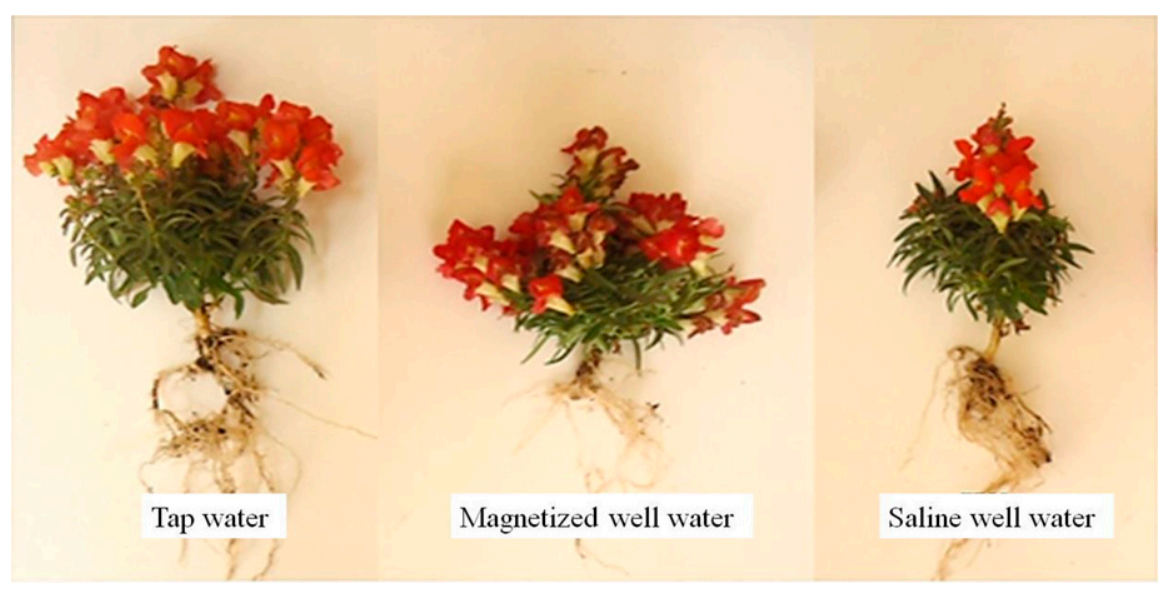

Fig. 2. Growth and flowering of representative $A$. majus plants in response to different irrigation water treatments.

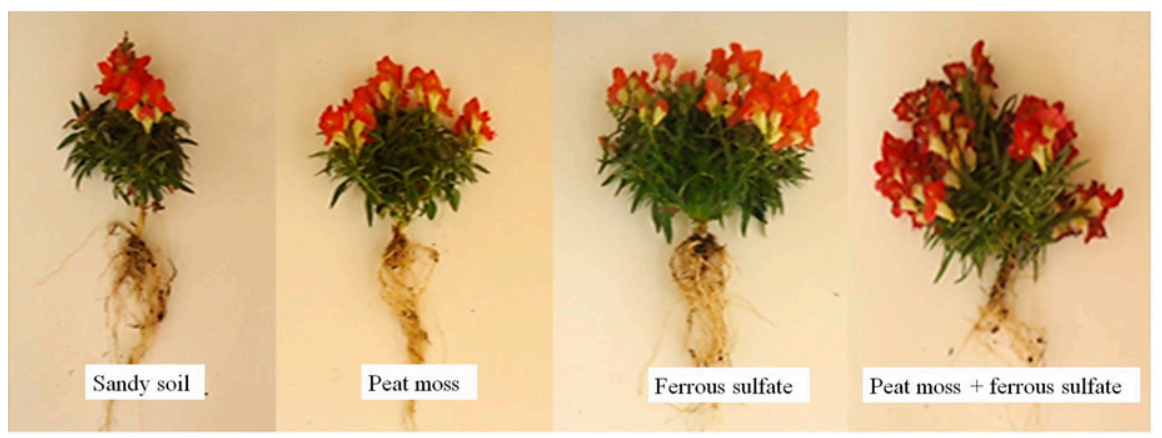

Fig. 3. Growth and flowering of representative $A$. majus plants in response to different soil amendments.

which in turn replaces $\mathrm{Na}^{+}$ions (Abd Elrahman et al., 2012).

Irrigation water type and soil amendments interacted significantly $(P \leq 0.05)$ to affect all vegetative growth parameters. Among all the treatments, tap water irrigation with the addition of peatmoss and $\mathrm{Fe}_{2} \mathrm{SO}_{4}$ resulted in the highest vegetative growth in plants (Table 2). Furthermore, soil amendments, applied either individually or in combination, significantly enhanced the growth of $A$. majus plants under all water irrigation types. Plants irrigated with tap water in soil amended with $\mathrm{Fe}_{2} \mathrm{SO}_{4}$ and peatmoss showed the highest vegetative growth responses, followed by plants cultivated in soils supplemented with $\mathrm{Fe}_{2} \mathrm{SO}_{4}$ and peatmoss and irrigated with magnetized water. Interestingly, plants irrigated with magnetized water without the addition of soil amendments grew better compared with those irrigated with saline water and supplemented with both $\mathrm{Fe}_{2} \mathrm{SO}_{4}$ and peatmoss. The negative effects of saline water on the growth of $A$. majus plants may also be attributed to the high osmotic pressure resulting from reduced water, imbalance between nutrients inside plant tissues, and the toxic and osmotic effects of sodium ions (Grieve et al., 2006). Overall, the vegetative growth parameters indicated that producing $A$. majus plants for cut flowers or ornamental
Inflorescence production and survival under different treatments. Magnetized saline water and nonmagnetized saline water produced plants with less inflorescences and flower dry matter as compared with control plants. However, water magnetization significantly enhanced the flowering productivity of A. majus. Specifically, irrigation with magnetized or saline water produced $A$. majus plants that flowered earlier than the control plants (Fig. 4A), which may be an avoidance strategy to cope with salinity stress, which is supported by the gradual delay in flowering in plants cultivated in soils supplemented with soil amendments, either individually or in combination. Interestingly, plants irrigated with magnetized saline water in soils amended with $\mathrm{Fe}_{2} \mathrm{SO}_{4}$ and peatmoss flowered at almost the same time as plants irrigated with tap water without any soil amendments, indicating that water magnetization and the addition of soil amendments are beneficial.

The results obtained in the current study show that soil supplementation with inorganic and/or organic amendments significantly increased fresh dry matter (FDM) and number of inflorescences per plant (Fig. 4B and C) regardless of irrigation water type. Peatmoss addition, especially, increased the number of inflorescences as compared with $\mathrm{Fe}_{2} \mathrm{SO}_{4}$ addition. This could be attributed to the increase in $\mathrm{CEC}$ due to the increased soil organic matter from peatmoss, which in turn enhances the retention of water and nutrients (Eyras et al., 2008). The results reveal that plants irrigated with magnetized saline water in soils amended with both $\mathrm{Fe}_{2} \mathrm{SO}_{4}$ and peatmoss achieve the second highest number of inflorescences after control plants in the soils amended with the same amendments. Similarly, plants irrigated with magnetized saline water in soils and 3 ).
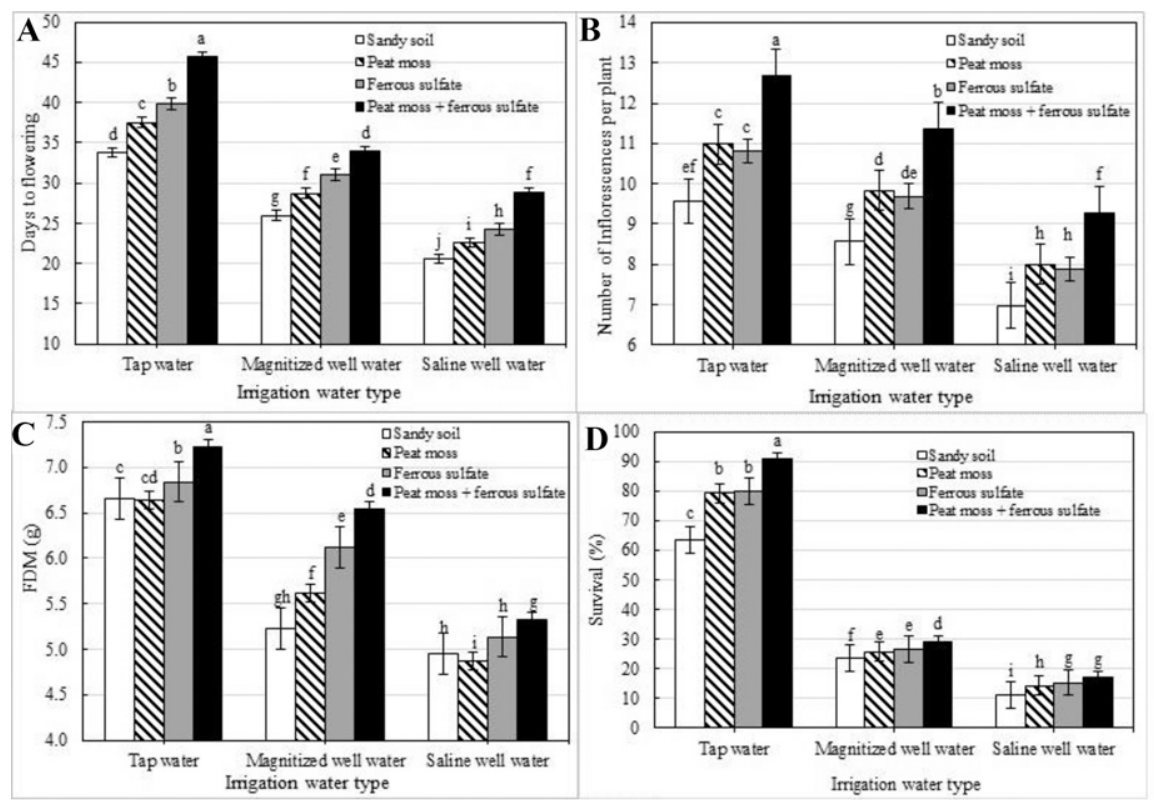

Fig. 4. Effects of different irrigation water types and soil amendments on inflorescence productivity of A. majus L. plants as indicated by days to flowering: (A) number of flowers per plant and (B) survival percentage. Values are shown as means (columns) \pm SEM (bars). Columns with the same letter are not significantly different $(P \leq 0.05)$. 


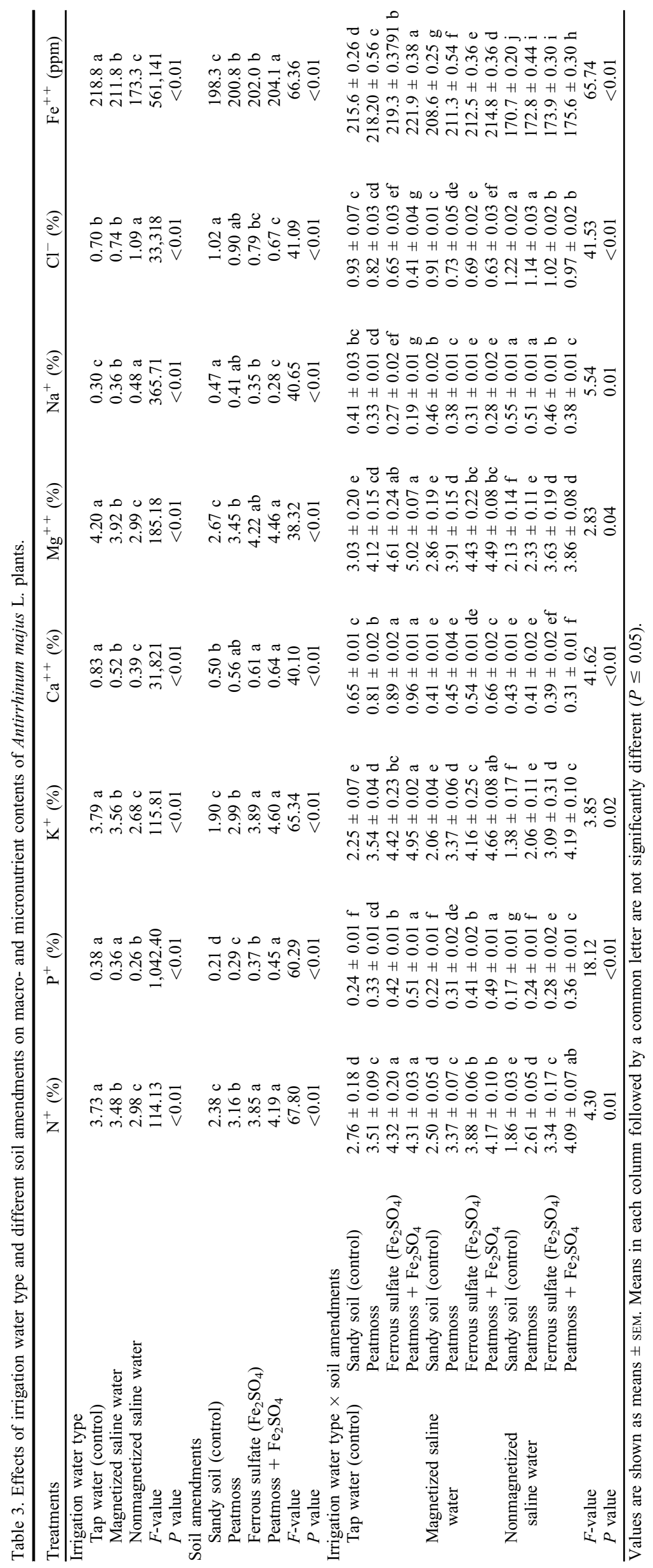

supplemented with $\mathrm{Fe}_{2} \mathrm{SO}_{4}$ and peatmoss had the highest FDM among noncontrol plants. It is possible that magnetization of saline water increases inflorescence production due to increased plant growth brought about by enhanced water absorption (Abdul-Qados and Hozayn, 2010). Moreover, nutrients in magnetized saline water are highly soluble and more available for plant uptake (Hilal and Hilal, 2000b).

Regardless of soil amendment, plants irrigated with tap water had the highest survival rates, ranging from $\approx 60 \%$ in soils without amendments to $95 \%$ in soils amended with both $\mathrm{Fe}_{2} \mathrm{SO}_{4}$ and peatmoss. On the other hand, the lowest survival rates $(10 \%$ to $20 \%)$ were observed in plants irrigated with nonmagnetized saline water. This is probably due to the inhibition of growth-promoting hormones, including auxins and cytokinins, resulting from salinity stress (Younis et al., 1987). The resulting reduction in growth may be the reason behind reduced survival rates in plants irrigated with nonmagnetized saline water. Furthermore, increased salinity tends to increase the osmotic pressure of the soil solution, which hinders water and nutrient absorption and adversely affects essential biological processes, especially photosynthesis (Prado et al., 2000). Irrigation with magnetized saline water significantly enhanced the survival rates of $A$. majus plants, which can be attributed to reduced size of magnetized saline water molecules that enhances water and nutrient absorption and permeability into roots, which in turn enhances overall plant growth and survival under stress conditions (Noran et al., 1996).

Changes in mineral contents. Plants irrigated with nonmagnetized saline water had the lowest contents of $\mathrm{N}^{+}, \mathrm{P}^{+}, \mathrm{K}^{+}, \mathrm{Ca}^{++}, \mathrm{Mg}^{++}$, and $\mathrm{Fe}^{++}$, and the highest levels of $\mathrm{Na}^{+}$and $\mathrm{Cl}^{-}$(Table 3). The reduced contents of different nutrients in the tissues of plants grown under salinity stress may be due to the diminished growth of roots (Elhindi et al., 2017), leading to reduced absorption of water and nutrients (Flowers and Colmer, 2008). Increasing the amount of dissolved salts in soil reduces the $\psi_{\mathrm{S}}$ of the soil solution (i.e., becomes more negative), thus increasing the difference between the water potentials of the soil and plant root solutions, leading to reduced water and nutrient absorption (Boland, 2006). On the other hand, irrigation with magnetized saline water enhanced plant nutritional status and decreased the contents of $\mathrm{Na}^{+}$and $\mathrm{Cl}^{-}$in A. majus tissues to levels comparable to those in control plants, indicating the potential of magnetization as a treatment for saline water.

Application of soil amendments, either individually or in combination, significantly enhanced $A$. majus nutritional status $(P \leq$ 0.05). Peatmoss increased the plant contents of all studied nutrients while lowering the contents of $\mathrm{Na}^{+}$and $\mathrm{Cl}^{-}$as compared with the contents in plants cultivated in soils supplemented with $\mathrm{Fe}_{2} \mathrm{SO}_{4}$ (Table 3). However, 
the application of both $\mathrm{Fe}_{2} \mathrm{SO}_{4}$ and peatmoss resulted in the highest plant nutrient contents among all the treatments. The mechanisms underlying the enhanced nutritional status of plants treated with inorganic and/or organic soil amendments include improved water movement and improved soil properties due to increased porosity, permeability, CEC, and moisture retention (Elhindi, 2012; Selim et al., 2009).

Water magnetization is beneficial because it reduces the surface tension of saline water, which improves the ability of roots to absorb water and nutrients, thus improving different biosynthetic processes (Elhindi et al., 2017). Irrigation with magnetized saline water and the addition of organic and inorganic amendments significantly enhanced the nutritional status of $A$. majus plants compared with control plants cultivated in sandy soil without amendments. However, irrigation with tap water combined with $\mathrm{Fe}_{2} \mathrm{SO}_{4}$ and peatmoss amendments produced plants with the highest contents of all studied nutrients, while lowering the $\mathrm{Na}^{+}$and $\mathrm{Cl}^{-}$contents (Table 3). Therefore, it could be concluded that water magnetization significantly alleviated the adverse effects of saline water on growth, productivity, and survival of $A$. majus. Furthermore, combining water magnetization with the application of inorganic and/or organic soil amendments, e.g., $\mathrm{Fe}_{2} \mathrm{SO}_{4}$ and peatmoss, respectively, enhanced the growth and inflorescence production of $A$. majus to levels comparable to those in plants irrigated with freshwater. We recommend further studies to examine the potential of using magnetized irrigation water for food crops, either alone or in combination with soil amendments.

\section{Literature Cited}

Abd Elrahman, S.H., M.A.M. Mostafa, T.A. Taha, M.A.O. Elsharawy, and M.A. Eid. 2012. Effect of different amendments on soil chemical characteristics, grain yield and elemental content of wheat plants grown on salt-affected soil irrigated with low quality water. Ann. Agr. Sci. 57:175-182, doi: 10.1016/j.aoas. 2012.09.001.

Abdul-Qados, A. and M. Hozayn. 2010. Response of growth, yield, yield components and some chemical constituents of flax for irrigation with magnetized and tap water. World Appl. Sci. J. 8:630-634.

Allen, S.E. 1989. Chemical analysis of ecological materials. 2nd ed. Blackwell Scientific, Oxford, UK.

Association of Official Analytical Chemists International (AOAC). 1990. Official methods of analysis. 15th ed. Association of Official Analytical Chemists Inc., Arlington, VA.

Black, C. 1965. Method of soil analysis part 2. Chem. Microb. Prop. 9:1387-1388.

Boland, A.-M. 2006. Management of saline and/or recycled water for irrigated horticulture. Acta Hort. 792:123-134, doi: 10.17660/ActaHortic. 2008.792.12.

Carter, C.T. and C.M. Grieve. 2008. Mineral nutrition, growth, and germination of Antirrhinum majus L. (Snapdragon) when produced under increasingly saline conditions. HortScience
43(3):710-718, doi: 10.21273/HORTSCI.43. 3.710 .

Elhindi, K.M. 2012. Evaluation of composted green waste fertigation through surface and subsurface drip irrigation systems on pot marigold plants (Calendula officinalis L.) grown on sandy soil. Aust. J. Crop Sci. 6: 1249-1259.

Elhindi, K.M., S.M. Al-Amri, E.M. Abdel-Salam, and N.A. Al-Suhaibani. 2017. Effectiveness of salicylic acid in mitigating salt-induced adverse effects on different physio-biochemical attributes in sweet basil (Ocimum basilicum L.). J. Plant Nutr. 40:908-919, doi: 10.1080/0190 4167.2016.1270311.

Eyras, M.C., G.E. Defossé, and F. Dellatorre. 2008. Seaweed compost as an amendment for horticultural soils in Patagonia, Argentina. Compost Sci. Util. 16:119-124, doi: 10.1080/ 1065657X.2008.10702366.

Ferrante, A., A. Trivellini, F. Malorgio, G. Carmassi, P. Vernieri, and G. Serra. 2011. Effect of seawater aerosol on leaves of six plant species potentially useful for ornamental purposes in coastal areas. Scientia Hort. 128:332-341, doi: 10.1016/ j.scienta.2011.01.008.

Flowers, T.J. and T.D. Colmer. 2008. Salinity tolerance in halophytes. New Phytol. 179:945-963, doi: 10.1111/j.1469-8137.2008.02531.x.

Gabr, S.S., E.F. Farg, T.M. Habeebullah, and S.M. Arafat. 2020. Irrigation water consumption and its impact on the groundwater aquifer of Wadi Uranah, Makkah, Saudi Arabia using remote sensing techniques. Egypt. J. Remote Sense. Space Sci. 23:167-180, doi: 10.1016/j.ejrs. 2018.10.001

Ghanati, F., S. Mohamadalikhani, M. Soleimani, R. Afzalzadeh, and A. Hajnorouzi. 2015. Change of growth pattern, metabolism, and quality and quantity of maize plants after irrigation with magnetically treated water. Electromagn. Biol. Med. 34:211-215, doi: 10.3109/ 15368378.2015.1076453.

Goyal, S., K. Chander, M.C. Mundra, and K.K. Kapoor. 1999. Influence of inorganic fertilizers and organic amendments on soil organic matter and soil microbial properties under tropical conditions. Biol. Fertil. Soils 29:196-200, doi: 10.1007/s003740050544.

Grieve, C.M., J.A. Poss, and C. Amrhein. 2006 Response of Matthiola incana to irrigation with saline wastewaters. HortScience 41:119-123, doi: 10.21273/HORTSCI.41.1.119.

Hachicha, M., B. Kahlaoui, N. Khamassi, E. Misle, and O. Jouzdan. 2018. Effect of electromagnetic treatment of saline water on soil and crops. J. Saudi Soc. Agr. Sci. 17:154-162, doi: 10.1016/j.jssas.2016.03.003.

Halvin, J.L., J. Beaton, S. Tisdale, and W. Nelson. 2005. Soil fertility and fertilizers: An introduction to nutrient management. Prentice Hall, Englewood Cliffs, NJ.

Hilal, M.H. and M.M. Hilal. 2000a. Application of magnetic technologies in desert agriculture. ISeed germination and seedling emergence of some crops in a saline calcareous soil. Egypt. J. Soil Sci. 40:413-422.

Hilal, M.H. and M.M. Hilal. 2000b. Application of magnetic technologies in desert agriculture. IIEffect of magnetic treatments of irrigation water on salt distribution in olive and citrus fields and induced changes of ionic balance in soil and plant. Egypt. J. Soil Sci. 40:423-435.

Hudson, A., J. Critchley, and Y. Erasmus. 2008. The genus Antirrhinum (Snapdragon): a flowering plant model for evolution and development. CSH. Protoc. 2008:pdb.emo100, doi: 10.1101/ pdb.emo100.
Jang, M., I. Hwang, B. Hwang, and G. Kim. 2020. Anti-inflammatory effect of Antirrhinum majus extract in lipopolysaccharide-stimulated RAW 264.7 macrophages. Food Sci. Nutr. 8:50635070, doi: 10.1002/fsn3.1805.

Kney, A.D. and S.A. Parsons. 2006. A spectrophotometer-based study of magnetic water treatment: assessment of ionic vs. surface mechanisms. Water Res. 40:517-524, doi: 10.1016/j.watres. 2005.11.019.

Kozminska, A., M. Al Hassan, D. Kumar, L. Oprica, F. Martinelli, M.N. Grigore, O. Vicente, and M. Boscaiu. 2017. Characterizing the effects of salt stress in Calendula officinalis L. J. Appl. Bot. Food Qual. 90:323-329, doi: 10.5073/JABFQ.2017.090.040.

Li, M., D. Zhang, Q. Gao, Y. Luo, H. Zhang, B. Ma, C. Chen, A. Whibley, Y.e. Zhang, Y. Cao, Q. Li, H. Guo, J. Li, Y. Song, Y. Zhang, L. Copsey, Y. Li, X. Li, M. Qi, J. Wang, Y. Chen, D. Wang, J. Zhao, G. Liu, B. Wu, L. Yu, C. Xu, J. Li, S. Zhao, Y. Zhang, S. Hu, C. Liang, Y. Yin, E. Coen, and Y. Xue. 2019. Genome structure and evolution of Antirrhinum majus L. Natl. Plants 5:174-183, doi: 10.1038/ s41477-018-0349-9.

Lian, Z., C.D. Nguyen, S. Wilson, J. Chen, H. Gong, and H. Huo. 2020. An efficient protocol for Agrobacterium-mediated genetic transformation of Antirrhinum majus. Plant Cell Tissue Organ Cult. 142:527-536, doi: 10.1007/ s11240-020-01877-4.

Mostafazadeh-Fard, B., M. Khoshravesh, S.-F Mousavi, and A.-R. Kiani. 2011. Effects of magnetized water and irrigation water salinity on soil moisture distribution in trickle irrigation. J. Irrig. Drain. Eng. 137:398-402, doi: 10.1061/(ASCE) IR.1943-4774.0000304

Munns, R. 2002. Comparative physiology of salt and water stress. Plant Cell Environ. 25: 239-250, doi: 10.1046/j.0016-8025.2001.00 808.x.

Noran, R., U. Shani, and I. Lin. 1996. The effect of irrigation with magnetically treated water on the translocation of minerals in the soil. Magn. Elec. Sep. 7:046596, doi: 10.1155/1996/ 46596.

Orcutt, D.M. and E.T. Nilsen. 2000. Physiology of plants under stress: Soil and biotic factors. John Wiley \& Sons, Hoboken, NJ.

Page, A.L. 1982. Methods of soil analysis, Part 2: Chemical and microbiological properties. American Society of Agronomy, Madison, WI.

Prado, F.E., C. Boero, M. Gallardo, and J.A. González. 2000. Effect of $\mathrm{NaCl}$ on germination, growth, and soluble sugar content in Chenopodium quinoa wild seeds. Bot. Bull. Acad. Sin. 41:27-34.

Selim, A.H. and M.F. El-Nady. 2011. Physioanatomical responses of drought stressed tomato plants to magnetic field. Acta Astronaut. 69:387-396, doi: 10.1016/j.actaastro. 2011.05.025.

Selim, A.H., M.A.H. Zayed, and M.A.T. Zayed. 2013 Magnetic field treated water effects on germination, growth and physio-chemical aspects of some economic plants. Acta Bot. Hung. 55:99-116, doi: 10.1556/ABot.55.2013.1-2.7.

Selim, E., A. Mosa, and A. El-Ghamry. 2009. Evaluation of humic substances fertigation through surface and subsurface drip irrigation systems on potato grown under Egyptian sandy soil conditions. Agr. Water Mgt. 96:1218-1222, doi: 10.1016/j.agwat.2009.03.018.

Surendran, U., O. Sandeep, and E.J. Joseph. 2016 The impacts of magnetic treatment of irrigation water on plant, water and soil characteristics. 
Agr. Water Mgt. 178:21-29, doi: 10.1016/j. agwat.2016.08.016.

Teixeira da Silva, J. and J. Dobránszki. 2014 Impact of magnetic water on plant growth. Environ. Expt. Biol. 12:137-142.
The Plant List. 2013. Version 1.1. Published on the Internet. 1 Jan. 2021. <http://www. theplantlist.org/>

Younis, M.E., M.N.A. Hasaneen, and M.M. Nemet-Alla. 1987. Plant growth, metabolism and adaptation in relation to stress conditions IV. Effects of salinity on certain factors associated with the germination of three different seeds high in fats. Ann. Bot. 60:337-344, doi: 10.1093/oxfordjournals.aob.a087453. 